\title{
Pengembangan Pembelajaran Bahasa Arab Berbasis Kecerdasan Musikal pada Mahasiswi Institut Parahikma Awaliyah Musgamy ${ }^{*}$ *
}

${ }^{1}$ Universitas Islam Negeri Alauddin Makassar

\section{ARTICLE INFO ABSTRACT}

ARTICLE HISTORY

Received: 09 Okt. 2019

Revised: 09 Okt. 2019

Accepted: 09 Okt. 2019

\section{KEYWORDS}

pembelajaran bahasa arab; kecerdasan musikal; arabic language learning; musical intelligence
Pengembangan pembelajaran bahasa Arab berbasiskan kecerdasan musikal pada siswa Institut Parahkma Indonesia dilakukan dengan mengadopsi lagu-lagu populer bagi siswa untuk dijadikan referensi dalam menghafal materi pembelajaran bahasa Arab. Peluang Pengembangan pembelajaran bahasa Arab berbasis kecerdasan musik pada siswa Institut Parahkma Indonesia adalah penggunaan media musik sebagai terapi pembelajaran yang telah digunakan sejak awal, kolaborasi kelembagaan yang memiliki kepedulian untuk belajar bahasa Arab, serta melibatkan siswa dalam mengembangkan pembelajaran strategi. Kendalanya adalah bahwa bahasa Arab menjadi bahasa asing kedua setelah bahasa Inggris, kualitas bahasa Arab masih buruk, pasif atau aktif, dan kecerdasan musik sering kontra produktif dengan tujuan pembelajaran.

The development of Arabic language learning based on musical intelligence in Indonesian Parahkma Institute students was carried out by adopting popular songs for students to further serve as a reference in memorizing Arabic learning materials. Opportunities The development of Arabic language learning based on musical intelligence in Indonesian Parahkma Institute students is the use of music media as learning therapy has been used since the beginning, institutional collaboration that has a concern for learning Arabic, as well as involving students in developing learning strategies. The obstacle is that Arabic becomes the second foreign language after English, the quality of the Arabic language is still poor, passive or active, and musical intelligence is often counter productive with learning goals. 


\section{PENDAHULUAN}

Pembelajaran bahasa Arab sebagai suatu pembelajaran bahasa asing di Indonesia mengalami berbagai banyak inovasi sebagai salah satu upaya mewujudkan pembelajaran bahasa Arab yang aktif, inovatif, kreatif, efektif, serta menyenangkan. Berbagai upaya ini muncul tentunya diliputi oleh berbagai fenomena pembelajaran bahasa Arab yang kurang menarik perhatian orang-orang untuk mempelajarinya. Bahkan saat bahasa Arab disandingkan dengan bahasa Inggris yang dalam lokus Indonesia sama-sama berposisi sebagai bahasa kedua, bahasa Inggris masih menunjukkan perkembangan yang lebih baik daripada bahasa Arab. Berbagai kesan negatif terkait bahasa Arab muncul satu persatu seperti bahasa yang sulit, bahasa yang kurang populer, dan semacamnya sehingga sedikit banyak berimplikasi pada rendahnya minat belajar peserta didik terhadap bahasa Arab.

Menyikapi hal tersebut, Suharsimi Arikunto menggambarkan bahwa minat belajar merupakan suatu hal yang penting karena tanpa minat maka peserta didik akn susah memusatkan perhatiannya pada apa yang dipelajari karena minat berkaitan dengan erat kecenderungan seseorang untuk kemudian menjatuhkan pilihan pada suatu hal, mengikuti atau meninggalkannya. Hadirnya minat membuat peserta didik akan memusatkan pada hal-hal yang diminatinya. ${ }^{1}$ Salah satu cara untuk mengembangkan minat belajar bahasa Arab peserta didik adalah dengan berinovasi pada pembelajaran bahasa Arab dengan mengadopsi berbagai pendekatan, metode, dan teknik pembelajaran bahasa Arab seperti yang ada di lingkungan Institut Parahikma Indonesia.

Institut Parahikma Indonesia merupakan salah satu perguruan tinggi yang memiliki perhatian dalam pengembangan pembelajaran bahasa Arab berbasis kecerdasan musikal. Hal ini ditegaskan oleh Abdullah Muhammad bahwa pihak kampus sangat mengakomodir munculnya berbagai inovasi pembelajaran bahasa Arab yang dilakukan oleh dosen-dosen termasuk dengan inovasi yang berkaitan dengan kecerdasan majemuk. ${ }^{2}$

Pengembangan pembelajaran bahasa Arab berbasis kecerdasan musikal merupakan suatu topik yang berkaitan erat dengan kecerdasan majemuk yang dimiliki oleh manusia sebagaimana digambarkan oleh Howard Gardner melihat kecerdasan manusia berdasarkan variannya yang sangat homogen. Dalam konsep kecerdasan majemuk yang dikemukakan dalam bukunya "Frames of Mind: The Theory of Multiple Intelligences", Howard Gardner membagi kecerdasan manusia atas delapan macam yang dalam hal ini adalah kecerdasan verbal-linguistik, kecerdasan logis-matematis, kecerdasan spasial-visual, kecerdasan kinestetik jasmani, kecerdasan musikal, kecerdasan intrapersonal, kecerdasan interpersonal, kecerdasan naturalis, serta kecerdasan eksistensial. ${ }^{3}$

Apa yang dikembangkan oleh Howard Gardner sebagai kecerdasan majemuk tersebut menujukkan bahwa setiap peserta didik pada dasarnya adalah makhluk yang memiliki kekhasan masing-masing yang layak ditonjolkan dalam pengembangan kapasistasnya, baik sebagai individu ataupun bagian dari struktur sosial. Menyikapi hal tersebut, Thomas Armstrong mengemukakan bahwa keunggulan pendidikan sebagai salah satu syarat untuk menghasilkan output yang yang berkualitas hanya dapat tercapai apabila setiap lembaga pendidikan memiliki kemampuan dalam membaca dan mengarahkan potensi yang imanen dalam diri setap peserta didik. Pendidikan yang ada selama ini cenderung hanya mengembangkan bagian terkecil dari potensi sebagian anak. ${ }^{4}$

Apa yang dipaparkan oleh Thomas Armstrong tersebut menunjukkan bahwa pendidikan yang bersifat monolit dalam upaya pengembangan kemampuan peserta didik, secara tidak langsung, mereduksi pengembangan begitu banyak potensi yang dimiliki oleh setiap anak yang sangat heterogen. Bisa dibayangkan dalam sebuah kelas yang terdiri atas beberapa orang dengan berbagai tipe kecerdasan majemeuk seperti kecerdasan verbal-linguistik, kecerdasan logis- 
matematis, kecerdasan spasial-visual, kecerdasan kinestetik-jasmani, kecerdasan musikal, kecerdasan intrapersonal, kecerdasan interpersonal, kecerdasan naturalis, serta kecerdasan eksistensial lalu kemudian yang dikembangkan hanya satu tipe kecerdasan saja maka bisa dibayangkan bagaimana dengan peserta didik yang kecerdasannya tidak terakomodir dalam kegiatan pembelajaran yang berlangsung. Pembelajaran semestinya berlangsung seperti pertunjukan band dengan perpaduan bunyi dari berbagai alunan alat musik tapi menghadirkan nada yang berirama serasi.

Dengan pengembangan pembelajaran bahasa Arab berbasis kecerdasan musikal, paling tidak, peserta didik yang memiliki afiliasi kecerdasan pada tipe ini dapat terakomodir sekaligus menjadi suatu teknik alternatif dalam pemebelajaran bahasa Arab yang selama ini bisa dikatakan cukup "alergi" dengan musik. Takdiroatun Musfiroh, dengan mengutip pendapat Armstrong, mengemukakan bahwa kecerdasan musikal adalah kemampuan menangani bentukbentuk musikal. Kemampuan tersebut meliputi, 1) kemampuan mempersepsi bentuk musikal, seperti menangkap atau menikmati musik dan bunyi-bunyi berpola nada, 2) kemampuan membedakan bentuk musikal, seperti mencipta dan memversikan musik, dan 3) kemampuan mengekspresikan bentuk musikal, seperti menyanyi, bersenandung, dan bersiul-siul. Hal ini berarti kecerdasan musikal adalah kemampuan mempersepsi dan memahami, mencipta dan menyajikan bentuk-bentuk musikal. ${ }^{5}$

Beberapa keuntungan yang dapat diperoleh dengan pengembangan pembelajaran bahasa Arab berbasis kecerdasan musikal digambarkan oleh Bagus H. Jihad dengan mengutip pendapat Schellenberg sebagai berikut:

a) Fokus perhatian untuk jangka waktu yang lama;

b) Membuat notasi musik (kompleks);

c) Menerjemahkan kode ke pola-pola gerakan yang tepat;

d) Mengenali pola suara di seluruh waktu;

e) Belajar aturan pembentukan pola;

f) Menghafal musik;

g) Memahami logik dan pecahan dalam musik;

h) Berimprovisasi terhadap aturan-aturan dasar musik. ${ }^{6}$

Dengan berbagai berbagai keuntungan yang diperoleh dengan pengembangan pembelajaran bahasa Arab berbasis kecerdasan musikal tersebut, diharapkan pembelajaran bahasa Arab yang selama ini terkesan kurang aktif, inovatif, kreatif, efektif dan menyenangkan dapat teratasi.

\section{METODE}

Penelitian ini tergolong jenis penelitian kualitatif deskriptif dengan Semi Research and Development (R\&D) dalam mengidentifikasi pengembangan pembelajaran bahasa Arab berbasis kecerdasan musikal pada Mahasiswi Institut Parahikma Indonesia. Dengan pendekatan pedagogis, penelitian ini dilaksanakan pada Mahasiswi Institut Parahikma Indonesia dengan yaitu dosen bahasa Arab dan mahasiswi. Informan awal dari subyek penelitian dipilih sebanyak 25 orang dengan rincian dosen bahasa Arab 2 orang, staf 1 orang dan mahasiswi 22 orang yang diambil dengan sampel bertujuan. Metode pengumpulan data yang digunakan adalah wawancara (interview), observasi partisipatif (participatory observation), dokumentasi (documentation), dan penelusuran referensi (reference exploration). Berdasarkan Model Miles dan Huberman, sebagaimana dikutip oleh Sugiyono, proses pengolahan dan analisis data dalam penelitian dilakukan melalui tiga tahapan secara berkesinambungan yang meliputi tahap reduksi data, tahap penyajian data, dan tahap penarikan kesimpulan/verifikasi. ${ }^{7}$ 


\section{HASIL DAN PEMBAHASAN}

\subsection{Pengembangan Pembelajaran Bahasa Arab Berbasis Kecerdasan Musikal pada Institut Parahikma Indonesia}

Pengembangan pembelajaran bahasa Arab berbasis kecerdasan musikal pada Institut Parahikma Indonesia dikembangkan dengan mengadopsi Metode Mumtaz dengan berbagai variasi lagunya. Salah satu lagu yang dinyayikan dalam menghafal tata bahasa Arab tersebut adalah tanda-tanda isim yang mengadopsi lagu "Anak Gembala" sebagai berikut:

Aku mengenal cirinya ISIM, 1) KASRAH dan 2) TANWIN baris akhirnya, 3) Berawalan AL atau 4) MA MI MU, 5) Muncul setelah AMILUL ISMI, 6) FA'ILUN, 7) NAMA-NAMA, 8) Terakhir KATA MAJEMUK.

Dalam upaya mengembangkan materi pembelajaran bahasa Arab berbasis kecerdasan musikal tersebut, peneliti memasukkan nada-nada yang sesuai dengan menggunakan ketukan-ketukan. Ketukan yang peneliti berikan di samping berfungsi sebagai nada terhadap lagu yang dinyanyikan juga berfungsi sebagai media yang menghilangkan rasa bosan mahasiswi selama mengikuti pembelajaran bahasa Arab. Riska Rabiana yang mengikuti pembelajaran bahasa Arab berbasis kecerdasan musikal tersebut mengaku sangat terbantu dalam memusatkan perhatian terhadap materi pembelajaran bahasa Arab yang diterapkan. ${ }^{8}$

Pada kesempatan lain, peneliti menemukan proses pembelajaran bahasa Arab berbasis kecerdasan musikal dengan dengan menggunakan lagu dengan judul "Menanam Jagung" dengan menekankan terkait dengan pembelajaran "Kana wa Akhwatuha" sebagai berikut:

\begin{tabular}{|c|c|c|c|c|}
\hline \multicolumn{5}{|c|}{ KAANA DAN SUADARA-SAUDARANYA } \\
\hline 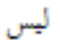 & صار & بات & 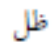 & كان \\
\hline
\end{tabular}

Dalam pelaksanaannya, pengembangan pembelajaran bahasa Arab berbasis kecerdasan musikal dilakukan denga terus melaukan inovasi sesuai dengan perkembangan blagu-lagu yang popular. Di samping itu, penggunaan media musik sebagai media terapi audio bagi mahasiswi selama proses pembelajaran bahasa Aab terus dilakukan. Menyikapi hal tersebut, Abdullah Jawawi menggambarkan bahwa dalam hal pemberian materi pembelajaran bahasa Arab di kelas-kelas, dia sering menggunakan musik-musik berbahasa Arab sebagai media untuk mengurangi kejenuhan belajar mereka. ${ }^{9}$

Upaya pengembangan yang peneliti lakukan adalah dengan melakukan pendampingan bagi para mahasiswi Institut Parahikma Indonesia untuk selalu mengembangkan inovasi pembelajaran bahasa Arab berbasis kecerdasan musikal. Hal ini peneliti lakukan dengan berkordinasi dengan dosen-dosen bahasa Arab di lingkungan Institut Parahikma Indoensia.

\subsection{Peluang Pengembangan Pembelajaran Bahasa Arab Berbasis Kecerdasan Musikal pada Institut Parahikma Indonesia}

Dalam pengembangan pembelajaran bahasa Arab berbasis kecerdasan musikal pada Institut Parahikma Indonesia, terdapat beberapa peluang yang dalam hal ini dapat dijabarkan sebagai berikut:

a) Penggunaan media musik sebagai terapi belajar sudah digunakan sejak awal

Institut Parahikma Indonesia dalam proses pembelajarannya, termasuk pembelajaran bahasa Arab, terus mengembangkan berbagai inovasi pembelajaran bahasa asing yang diharapkan mampu untuk meningkatkan minat belajar bahasa asing mahasiswinya. Hal ini menjadi peluang pengembangan pembelajaran bahasa Arab berbasis kecerdasan musikal karena mahasiswi mengingat sudah ada pembiasaan yang dilakukan dari awal dan mereka sudah terbiasa dengan hal terebut. Fathurrahman yang merupakan staf sekaligus pembina UKM Seni pada Institut 
Parahikma Indonesia menyatakan bahwa penggunaan media musik pada awalnya dikembangkan dengan mengadopsi metode suggestoedia dalam pembelajaran bahasa Inggris yang berfungsi untuk meningkatkan perhatian belajar mahasiswi pada materi ajar dan proses pembelajarannya. Hal ini dilakukan dengan membiasakan mereka mendengar lagu-lagu berbahasa asing dengan irama yang lembut sehingga selama kegiatan pembelajaran sehingga mereka tidak bosan dalam belajar. ${ }^{10}$

Apa yang disampaikan oleh Fathurrahman tersebut menunjukkan bahwa pengembangan kecerdasan musikal dalam lingkungan Institut Parahikma Indonesia sudah dilakukan dari dulu. Tinggal kemudian pengembangannya perlu dilakukan dengan meningkatkan materi serta teknik penyampaian terapi musik itu sendiri dengan berbagai variasinya. Abdullah Jawawi mengemukakan bahwa penggunaan lagu-lagu tertentu dengan irama yang khas sebagai dasar dari proses penghafalan kaidah-kaidah bahasa tertentu juga menjadi salah satu peluang pengembangan pembelajaran bahasa Arab berbasis kecerdasan musikal dalam lingkungan Institut Parahikma Indonesia karena dosen-dosen bahasa Arab juga terbiasa melakukan hal tersebut dimana hapalan mufradat ataupun tata bahasa Arab apabila dihafal sambil dinyayikan maka mahasiswi lebih mudah untuk menghafal dan mengingat kembali apabila mereka butuhkan pada tempat dan waktu yang berbeda. ${ }^{11}$

b) Kerjasama kelembagaan yang memiliki perhatian terhadap pembelajaran bahasa Arab

Peluang lain dari pengembangan pembelajaran bahasa Arab berbasis kecerdasan musikal Institut Parahikma Indonesia adalah banyaknya kerjasama yang telah dilakukan dengan beberapa lembaga yang memiliki perhatian terhadap pembelajaran bahasa Arab yang salah satunya adalah UKM Seni dan Budaya UIN Alauddin Makassar. Menyikapi hal tersebut, Fathurrahman mengemukakan bahwa posisinya sebagai pembina UKM yang berkaitan dengan seni pada dua kampus yang dalam hal ini adalah UIN Alauddin Makassar dan Institut Parahikma Indonesia mendorongnya untuk membangun simbiosis mutualisme pada dua PTKI yang lokasinya berdekatan tersebut. Dalam pengimplementasiannya, anak-anak KM Seni dan Budaya UIN Alauddin Makassar melakukan latihan bersama dengan anak-anak UIKM Seni Institut Parahikma Indonesia khususnya dalam hal bagaimana bermain musik dan berbagai keterampilan seni lainnya.12 Dalam pengamatan peneliti, setiap akhir pekan, latihan bersama ini dilakukan secara rutin di kampus 1 Institut Parahikma Indonesia.

Di samping kerjasama antar lembaga kemahasiswaan, peluang lain dari pengembangan pembelajaran bahasa Arab berbasis kecerdasan musikal Institut Parahikma Indonesia adalah dengan adanya kerjasama dengan Yayasan Ikhlas Jakarta yang mengembangkan metode pembelajaran bahasa Arab dengan Metode Mumtaz. Metode yang awalnya dikembangkan oleh Alimin Mesra dan Saifuddin Zuhri ini fokus pada pengembangan penghafalan tata bahasa Arab dengan mengadopsi berbagai lagu seperti lagu religi, lagu dangdut, lagu anak-anak, lagu daerah, dan semacamnya yang sebagai acuan dalam menghafal tata bahasa Arab. Menyikapi hal tersebut, Abdullah Muhammad yang telah menggambarkan bahwa metode ini sangat berpeluang untuk dikembangkan pada mahasiswi Institut Parahikma Indonesia karena suasana pembelajaran menjadi sangat menarik. Hanya saja, dia yang pernah diutus oleh lembaga untuk mengikuti pelatihan pembelajaran bahasa Arab dengan Metode Mumtaz di Pondok Pesantren DDI Mangkoso Barru belum menghafal secara keseluruhan bagaimana menyanyikan teks-teks lagu yang dipilih dari Metode Mumtaz untuk menghafal tata bahasa Arab sehingga diperlukan suatu upaya follow up untuk kerjasama tersebut berupa pelatihan khusus di lingkungan Institut Parahikma Indonesia. ${ }^{13}$

\subsection{Pelibatan mahasiswi dalam pengembangan strategi pembelajaran}

Pelibatan mahasiswi dalam pengembangan strategi pembelajaran menjadi suatu peluang pengembangan pembelajaran bahasa Arab berbasis kecerdasan musikal Institut Parahikma 
Indonesia. Dalam pengamatan peneliti, hal ini terwujud karena rata-rata dosen pada lembaga pendidikan tinggi yang dididrikan oleh Azhar Arsyad ini merupakan fresh graduate dari berbagai perguruan tinggi, baik dalam negeri ataupun luar negeri seperti Amerika, Australia, Inggris, Belanda, Tunisia, dan yang lainnya. Salah satu inovasi pembelajaran yang mereka lakukan dalam melibatkan mahasiswi untuk mengembangkan strategi pembelajaran adalah dengan selalu memberikan kesempatan pada mereka untuk menyampaikan masukan konstruktif baik di awal ataupun di akhir perkuliahan setiap tatap muka.

Nurhawaisyah yang merupakan mahasiswi Program Studi Tadris Bahasa Inggris mengemukakan bahwa dosen-dosen sangat kreatif dalam melibatkan mereka untuk berpartisipasi aktif dalam kegiatan pembelajaran bahasa asing termasuk dengan menjadikan mereka sebagai mursyid untuk membimbing mahasiswi yunior mereka.14 Dalam proses tersebut, para mursyid diberikan peluang untuk berinovasi dengan berbagai pendekatan, metode dan teknik yang tentunya tetap di bawah pengawasan dan arahan dari dosen bahasa Arab sebagai musyrif.

\subsection{Hambatan Pengembangan Pembelajaran Bahasa Arab Berbasis Kecerdasan Musikal pada Institut Parahikma Indonesia}

Dalam pengembangan pembelajaran bahasa Arab berbasis kecerdasan musical pada Institut Parahikma Indonesia, sebagaimana adanya peluang, juga terdapat beberapa habatan yang dalam hal ini dapat dijabarkan sebagai berikut:

a) Bahasa Arab menjadi bahasa asing kedua setelah bahasa Inggris

Institut Parahikma Indonesia merupakan salah satu lembaga pendidikan tinggi yang mengusung trilogi pengembangan akademik yang dalam hal ini adalah bahasa Inggris, Information, Communication and Technology (ICT), serta pendidikan karakter. Tidak masuknya bahasa Arab sebagai fokus pengembangan dalam trilogi pengembangan akademik Institut Parahikma Indonesia tentu menjadi hambatan tersendiri mengingat posisinya sama-sama sebagai bahasa asing.

Abdullah Jawawi menjelaskan bahwa tidak masuknya bahasa Arab sebagai fokus pengembangan dalam trilogi pengembangan akademik Institut Parahikma Indonesia membuat dosen bahasa Arab harus berinovasi dalam interaksi pembelajaran bahasa Arab di kelas atau di luar kelas dengan mengambil perbandingan terkait berbagai pendekatan, metode dan teknik yang dikembangkan dalam pembelajaran bahasa Inggris sebagai bahasa prioritas termasuk dengan mengadopsi pengembangan pembelajaran bahasa asing berbasis kecerdasan musikalnya. ${ }^{15}$

b) Masih rendahnya kualitas bahasa Arab mahasiswi, pasif ataupun aktif

Sama dengan berbagai kasus pada PTKI yang berada di luar Jawa, input mahasiswi baru yang masuk pada Institut Parahikma Indonesia mayoritas masih memiliki kemampuan bahasa Arab yang rendah, baik aktif ataupun pasif. Abdullah Muhammad menggambarkan bahwa apabila mau dirata-ratakan maka dalam 10 mahasiswi mungkin hanya 3-4 yang pernah belajar bahasa Arab sebelumnya. Hal ini menjadi hambatan tersendiri sehingga dengan pengembangan pembelajaran bahasa Arab berbasis kecerdasan musikal tersebut, mahasiswi diharapkan dapat termotovasi untuk belajar bahasa Arab yang seringkali dianggap sebagai materi perkuliahan yang sulit untuk dipelajari. ${ }^{16}$

Hambatan ini hampir ditemkan pada berbagai PTKI yang menjadikan bahasa Arab, baik sebagai salah satu program studi dengan berbagai rumpung keilmuan bahasa Arab dan pembelajarannya ataupun sebagai Mata Kuliah Dasar Umum (MKDU), dimana ouput mahasiswi baru yang masuk biasanya memiliki kemampuan bahasa Arab yang masih rendah dan perlu dikembangkan. 
c) Kecerdasan musikal seringkali kontra produktif dengan tujuan pembelajaran

Pada dasarnya, kecerdasan musikal sebagai sebuah tipe kecerdasan yang menekankan sisi hiburan dengan tidak melupakan proses pembelajaran itu sendiri. Dalam konteks tersebut, pengembangan pembelajaran bahasa Arab berbasis kecerdasan musikal Institut Parahikma Indonesia dilakukan untuk memberikan nuansa baru pada pembelajaran bahasa Arab yang aktif, inovatif, kreatif, efektif serta menyenangkan. Untuk mewujudkan hal tersebut, maka penggunaan berbagai media pembelajaran termasuk dengan penggunaan gadget untuk browsing dan searching berbagai jenis musik kadang-kadang menjadi kontra produktif dengan tujuan pembelajaran bahasa Arab yang erlangsung karena ada juga mahasiswi yang kadangkadang membuka aplikasi lain seperti Whattsap, Facebook, dan semacamnya.

Menyikapi hal tersebut, Abdullah Muhammad menggambarkan bahwa pengawasan yang ketat oleh dosen selama proses perkuliahan menjadi salah satu kunci dalam mengatasi hambatan tersebut. Dia juga menambahkan fitur LMS (Learning Management System) yang dikembangan di lingkungan Institut Parahkma Indonesia sebagai salah satu sistem pembelajaran online diharapkan mampu mereduksi akses mahasiswi pada berbagai aplikasi yang tidak sejalan dengan program pembelajaran. ${ }^{17}$

\section{SIMPULAN}

Pengembangan pembelajaran bahasa Arab berbasis kecerdasan musikal pada mahasiswi Institut Parahkma Indonesia dilakukan dengan mengadopsi lagu-lahu yang popular bagi mahasiswi untuk selanjutnya dijadikan sebagai acuan dalam menghafal materi pembelajaran bahasa Arab. Peluang Pengembangan pembelajaran bahasa Arab berbasis kecerdasan musikal pada mahasiswi Institut Parahkma Indonesia adalah penggunaan media musik sebagai terapi belajar sudah digunakan sejak awal, kerjasama kelembagaan yang memiliki perhatian terhadap pembelajaran bahasa Arab, serta pelibatan mahasiswi dalam pengembangan strategi pembelajaran. Adapun hambatannya adalah bahasa Arab menjadi bahasa asing kedua setelah bahasa Inggris, masih rendahnya kualitas bahasa Arab mahasiswi, pasif ataupun aktif, serta kecerdasan musikal seringkali kontra produktif dengan tujuan pembelajaran.

\section{DAFTAR PUSTAKA}

Arikunto, Suharsimi, Manajemen Pengajaran Secara Manusiawi, Jakarta: Rineka Cipta, 1990. Armstrong, Thomas, Setiap Anak Cerdas, Jakarta: PT Gramedia Pustaka Utama, 2003.

Jihad, Bagus H., Cara Mengembangkan Kecerdasan Musikal, http://baguserek.blogspot.com/2012/02/cara-mengembangkan-kecerdasan-musikal.html. (10 Juli 2019)

Kartianom, Kartianom, and Oscar Ndayizeye. "What's Wrong with the Asian and African Students' Mathematics Learning Achievement? The Multilevel PISA 2015 Data Analysis for Indonesia, Japan, and Algeria." Jurnal Riset Pendidikan Matematika 4, no. 2 (2017): 200-210.

Kartianom, Kartianom. "Diagnosis Kesalahan Konsep Materi Matematika SMP Berdasarkan Hasil Ujian Nasional Di Kota Baubau.” UNY, 2017.

Musfiroh, Takdiroatun, Pengembangan Kecerdasan Majemuk, Jakarta: Universitas Terbuka, 2008.

Sugiyono, Metode Penelitian Pendidikan: Pendekatan Kuantitatif, Kualitatif, dan R\&D, Bandung: Alfabeta, 2008.

Sujiono, Yuliani Nurani dan Bambang Sujiono, Bermain Kreatif Berbasis Kecerdasan Jamak, Indonesia: PT Indeks, 2010. 